\title{
Conservation paradox of giant arapaima Arapaima gigas (Schinz, 1822) (Pisces: Arapaimidae): endangered in its native range in Brazil and invasive in Indonesia
}

\author{
Jana Marková ${ }^{1}$, Rikho Jerikho ${ }^{2}$, Yusli Wardiatno ${ }^{2,3}$, Mohammad Mukhlis Kamal ${ }^{3}$, \\ André Lincoln Barosso Magalhães ${ }^{4}$, Lucie Bohatá ${ }^{,}$, Lukáš Kalous ${ }^{1}$ and Jiří Patoka ${ }^{1, *}$ \\ ${ }^{1}$ Department of Zoology and Fisheries, Faculty of Agrobiology, Food and Natural Resources, Czech University of Life Sciences Prague, \\ Kamýcká 129, Praha - Suchdol 16500, Czech Republic \\ 2 Environmental Research Center, IPB University, Kampus IPB Dramaga, Bogor 16680, Indonesia \\ ${ }^{3}$ Department of Aquatic Resources Management, Faculty of Fisheries and Marine Sciences, Bogor Agricultural University, Bogor 16680, \\ Indonesia \\ ${ }^{4}$ Rua Professor Arduíno Bolivar, 80, Belo Horizonte, Minas Gerais 30350-140, Brazil
}

Received: 23 September 2020 / Accepted: 24 November 2020

\begin{abstract}
Ornamental aquaculture is known to be one of the main sources of non-native species and Indonesia has been identified as one of the leading suppliers of these organisms worldwide. Released or escaped ornamental aquatic animals can establish new populations and become invasive. On the other hand, some invasive species can be also endangered in their native range, which is called the "Biodiversity Conservation Paradox". This is true for Arapaima gigas, one of the popular ornamental creatures and the largest bony fish of all, which is threatened in its native range in parts of Amazonia and which has been found to occur in various localities in Java and Sumatra in Indonesia. Based on climate matching we found the vast majority of Indonesian territory to be suitable for this species establishment. Keeping in mind the size and predatory behaviour of $A$. gigas, we discussed possible consequences of its spread and impacts on native biota in Indonesia.
\end{abstract}

Keywords: Biological invasion / Osteoglossiformes / Ornamental species / Asia / Climate matching

Résumé - Paradoxe de conservation de l'arapaima géant Arapaima gigas (Schinz 1822) (Poisson: Arapaimidae): en danger dans son aire de répartition naturelle au Brésil et envahissant en Indonésie. L'aquaculture ornementale est connue pour être l'une des principales sources d'espèces non indigènes et l'Indonésie a été identifiée comme l'un des principaux fournisseurs de ces organismes dans le monde. Les animaux aquatiques ornementaux relâchés ou échappés peuvent établir de nouvelles populations et devenir envahissants. D'autre part, certaines espèces envahissantes peuvent également être menacées dans leur aire de répartition d'origine, ce que l'on appelle le "paradoxe de la conservation de la biodiversité". C'est le cas de l'Arapaima gigas, une des créatures ornementales les plus populaires et le plus grand poisson osseux de tous, qui est menacé dans son aire de répartition naturelle dans certaines parties de l'Amazonie et dont la présence a été constatée dans diverses localités de Java et de Sumatra en Indonésie. En se basant sur la correspondance climatique, nous avons constaté que la grande majorité du territoire indonésien est propice à l'établissement de cette espèce. En gardant à l'esprit la taille et le comportement prédateur d'A. gigas, nous avons discuté des conséquences possibles de sa propagation et de ses impacts sur le biote indigène en Indonésie.

Mots-clés : Invasion biologique / Ostéoglossiformes / Espèces ornementales / Asie / correspondance climatique

\footnotetext{
*Corresponding author: patoka@af.czu.cz
} 


\section{Introduction}

Human activities are partly responsible for a decline in global biodiversity (Ilheu et al., 2014). In order to mitigate devastating consequences, the importance of nature conservation is highlighted (Cristescu and Boyce, 2013; AzevedoSantos et al., 2017). Even if it is not a panacea, critically endangered species should be protected if we would like to give them a chance to survive (Ceballos et al., 2015). However, as many have pointed out, there is also the other side of the coin in the case of some endangered species becoming invasive and spreading outside of their native range with various negative environmental and socio-economic impacts (Lees and Bell, 2008; Garzón-Machado et al., 2012; Bellard et al., 2016; Marchetti and Engstrom, 2016).

Endangered species are not usually invaders. But once in a while, certain species become both endangered within its native range and at the same time establish non-native populations in a new location, where they spread and behave as invaders. This phenomenon is generally called the "Biodiversity Conservation Paradox" (Vellend, 2017). For instance, the large omnivorous wattle-necked soft-shelled turtle (Palea steindachneri) is endangered in China and Vietnam but also has invasive populations in Hawaii (Ernst and Lovich, 2009), the Republic of Mauritius and the Sacramento River in California (Radford, 2011). European wild rabbit (Oryctolagus cuniculus), the protected keystone species in Iberia, has a welldocumented destructive influence in Australia (Lees and Bell, 2008). Another invader in Australia is banteng, also known as tembadau (Bos javanicus), a species of wild cattle, which is endangered in Bali and Java (Bradshaw et al., 2006). One can mention also the invasions of aoudad (Ammotragus lervia) and mouflon (Ovis orientalis) in the Canary Islands, while both species are endangered in their native ranges (GarzónMachado et al., 2012). Also, some species potentially endangered in the native range and more or less invasive in regions where introduced are known: for example, narrowclawed crayfish (Pontastacus leptodactylus) native to East Europe and introduced to many other European regions (Kouba et al., 2014).

Although the expected solution to invasive species is eradication - as most methods of conservation recommends (sensu Lockwood et al., 2013 and citations therein; Schofield et al., 2019) -, this approach is not universally advised (Casazza et al., 2016). In many cases, the newly introduced species can damage the penetrated ecosystem (Schofield et al., 2019). But in some other instances, the invasive species can help to protect some endangered species and its eradication could harm the already damaged species even more, as in the case of the invasive grass Spartina spp. in California where these plants have created new nesting habitat for an endangered bird, Ridgway's rail (Rallus obsoletus) (Lampert et al., 2014). In these situations, and in relation to the Biodiversity Conservation Paradox, the eradication is at least disputable and the best solution must be thoroughly discussed by experts in the field (Marchetti and Engstrom, 2016).

One of the most important pathways for introduction of non-native species is the international pet trade (Early et al., 2016; Novák et al., 2020; Patoka et al., 2020a,b). Freshwater animals exploited for ornamental purposes sometimes escape or are both intentionally or accidentally released from aquaria or garden ponds (Padilla and Williams, 2004; Kalous et al., 2015; Patoka et al., 2017; Magalhães et al., 2017b; Schofield et al., 2019). One can find various examples of pet traded aquatic animals behaving as invaders such as: lionfish (Pterois volitans) in the Atlantic Ocean (Green et al., 2012) and Mediterranean Sea (Kletou et al., 2016); guppy (Poecilia reticulata) and swordtail (Xiphophorus helleri) in Australia and Brazil respectively (Maddern et al., 2011; Magalhães and Jacobi, 2017); red-eared slider (Trachemys scripta elegans) which is now present in all continents except Antarctica (Lever, 2003; Ramsay et al., 2007; Ernst and Lovich, 2009; Héritier et al., 2017); marbled crayfish (Procambarus virginalis) in European freshwaters (Lőkkös et al., 2016; Pârvulescu et al., 2017; Hossain et al., 2018); and the cichlid fishes bay snook (Petenia splendida) and blue mbuna (Labeotropheus fuelleborni) in USA (Schofield et al., 2019). Introduced species can cause decline or extinction of native biota by predation, resource competition, habitat alteration (Pimentel, 2014; Forneck et al., 2016), and also by introducing new pathogens (Gozlan et al., 2009; Putra et al., 2018).

In some regions, the consequences of non-native species introductions to the wild are overlooked or ignored also at the policy level (Liang et al., 2006; Marchetti and Engstrom, 2016; Patoka et al., 2020a,b). Even if the pet trade in selected aquatic species is regulated by both national and international legislation in certain regions, their effectiveness is at least questionable in some cases because hobbyists often do not know reasons why stocking and keeping of mentioned species is prohibited and are not aware of risks of biological invasions (Magalhães, 2015; Patoka et al., 2018a). Also, the release of unwanted pets because they require more food, overpopulate, or outgrow the tank, are not so attractive in colouration in adult stage, or become very aggressive is a relatively common practice among hobbyist generally (Duggan et al., 2006; Magalhães et al., 2017b).

Among the leading producers and exporters of freshwater animals for ornamental purposes is Indonesia (Wood, 2001; Patoka et al., 2015). The tropical climate in this country is favourable for keeping of ornamental fish and other aquatic species in outdoor reservoirs or natural lakes and the culture of non-native species is not regulated within the country (Patoka et al., 2018a). Moreover, one of six main religions in Indonesia is Buddhism, where a ceremony known as "fang sheng" (a ritual of releasing living creatures) refers to the practice of purchasing animals, particularly birds or fish, to subsequently release them to the wild to demonstrate Buddhist pity and to gather merits for a favourable judgement in the afterlife (Shiu and Stokes, 2008). The non-native animals escaped or released as unwanted pets or via the "fang sheng" rite, usually starve or are preyed on and die quickly, or, if they are able to survive, become feral pests that could threaten the native biota as invaders.

Thus, various non-native freshwater species have been recorded in Indonesia: for example the crayfish Cherax quadricarinatus (Patoka et al., 2018b) and Procambarus clarkii (Putra et al., 2018), molluscs Pomacea canaliculata and P. insularum (Marwoto and Nur, 2011), Sinanodonta woodiana (Bolotov et al., 2016), and fishes such as guppy (P. reticulata) (Knight, 2010), alligator gar (Atractosteus spatula) (Muchlisin, 2012), Amazon sailfin catfish (Pterygoplichthys disjunctivus and P. pardalis) (Muchlisin et al., 2015; 
Patoka et al., 2020a,b) and red-eared slider turtle (Trachemys scripta elegans) (Ramsay et al., 2007).

The carnivorous fish Arapaima gigas (Schinz, 1822) (Osteoglossiformes: Arapaimidae) is also called "pirarucu" in Brazil and Colombia or "paiche" in Peru, Ecuador, Venezuela and Bolivia, or simply giant arapaima. It has a native range in Central South America and it is the largest freshwater scaled fish in the world, growing up to $3 \mathrm{~m}(9.8 \mathrm{ft})$ in body length and $200 \mathrm{~kg}$ in weight over the course of its lifespan (Castello and Stewart, 2010). In the genus Arapaima, there are four species distinguished (Stewart, 2013) although molecular studies (Hrbek et al., 2005; Araripe et al., 2013) are contrasting with this statement, suggesting structured populations. The most probably only $A$. gigas is pet-traded (Nijman, 2010). This charismatic "ancient" creature that belongs to a primitive group of carnivorous bony-tongued fishes is an ideal candidate for ornamental fishkeeping especially in smaller sizes (i.e., juveniles and subadults). It is pet-traded in Europe, North America, South America and also in Asia (Mueller and Green, 2005; Magalhães et al., 2017b), although protected by the Convention on International Trade in Endangered Species of Wild Fauna and Flora (CITES, Appendix II) (Nijman, 2010).

Arapaima gigas is threatened by overfishing for human consumption in its native range in Brazil, mainly due to its obligatory air-breathing behaviour (Hrbek et al., 2007). Since it gulps atmospheric oxygen above the water surface every 5-15 min, it is a very easy target for harpoon-specialist fishermen (Castello, 2004; Hrbek et al., 2007). The commercial fishing of giant arapaima has been limited to a sustainable level from 2001, but illegal capture still exists and about 77\% of the harvest is unlawful (Hrbek et al., 2007). To reduce pressure on wild populations, A. gigas is also produced in aquaculture in Brazil (Imbiriba, 2001; de Oliveira et al., 2012). This production is increasing in recent years (Lima Junior et al., 2018; Nobile et al., 2019). On the other hand, young Arapaima individuals can be collected from the wild in Brazil, kept in captivity and subsequently exported abroad as captivebred fish, which has been routinely done by traders (Castello and Stewart, 2010).

Despite its relatively high abundance in the past, $A$. gigas became extinct in the surroundings of big Amazonian cities after 1970s (Goulding, 1980). In this regard, it was added to The IUCN Red List of Threatened Species (Baillie and Groombridge, 1996) and classified as "Data Deficient", because detailed data about its distribution and abundance are lacking. There are community-based initiatives protecting suitable waterbodies to allow $A$. gigas naturally reproduce and form sustainable populations within its native range (Castello, 2004). Unfortunately, decreasing abundance has led to a very low degree of polymorphism which represents one of the major problems for future conservation management (Torati et al., 2019).

Out of its native range, $A$. gigas is known to behave as an invasive species in parts of Brazil (Fontenele, 1955; Ferreira, 2013; Ramos et al., 2014; Casimiro et al., 2018; da Costa Doria et al., 2020), south-eastern Peru and north-western Bolivia where it was introduced for control of undesirable species such as piranhas (Pygocentrus spp., Serrasalmus spp.) and from intentional releases or aquaculture purposes (Miranda-Chumacero et al., 2012; Van Damme et al., 2015). At least in Bolivia, it has probably caused a reduction of native ichthyofauna including species of high commercial value such as small characids (Van Damme et al., 2015).

As mentioned above, once established in culture, A. gigas has been also exported for human consumption and as an ornamental species, from Brazil, Colombia and Peru (Mueller and Green, 2005) or from countries outside South America, such as Cambodia, India, Indonesia, and Thailand (Vidthayanon, 2005), even if this is somewhere illegal as in India (Kumar et al., 2019). Authorities in the importing countries are aware about the potential invasive behaviour of large non-native predatory fish species but the restrictions are ineffective in many cases, turning laws into "dead letters", that is, existing but unenforced laws (Patoka et al., 2018a). For example, although the Indonesian Ministry of Agriculture established the law No. 179/Kpts/UM/3/1982, updated as the law No. PERMENKP/41/2014, to ban the import of certain fish species including $A$. gigas to the country, this species is widely traded as ornamental animal there (Patoka, 2018). Moreover, the continuous illegal import to Indonesia cannot be excluded (Priono and Satyani, 2010) and general knowledge about its potential escapes or release of this species in the wild is poor. Just one record from Indonesian territory was published (Fadjar et al., 2019). Unfortunately, the finding was described without detailed evidence and should be perceived as somewhat uncertain.

For this reason, we decided: (i) to survey selected localities in Indonesia; (ii) to ascertain the probability that this fish occurs and survives within Indonesian waterbodies by climate matching; and (iii) to discuss the conservation paradox implications, with recommendations on how to manage the situation.

\section{Material and methods}

\subsection{Data collection}

Records of $A$. gigas in Indonesian freshwaters were gathered from June 2011 to July 2018. The inventory of its occurrences in Indonesian waterbodies was done through desk study in several local online news media and social media (Facebook ${ }^{\circledR}$, www.facebook.com). Online findings that indicated the occurrence of the species were confirmed through photographic evidence, personal interviews with local residents and fishermen and, if possible, also by direct observations. In direct observations, body parts of captured Arapaima that were still possible to be analysed genetically were preserved in $96 \%$ alcohol. All activities were conducted with respect to Indonesian laws and ethical rules and guaranteed by Indonesian academic staff.

\subsection{Species determination}

For morphological analysis, a comparison of shape of the dorsalmost lateralis sensory cavity on the preopercle as described by Stewart (2013) was used. The species identification was verified by genetic analysis using polymerase chain reaction (PCR). DNA was isolated from tissue of the voucher individual and the region of the coxl gene from mitochondrial DNA was amplified in PCR reaction using primers FishF1 and FishR2 and PCR protocol according to Ward et al. (2005). 
The PCR products were visualized and sequenced at SEQme s.r.o. in the Czech Republic (https://www.seqme.eu/cs/). Chromatograms were assembled and checked for potential errors. Edited sequences were aligned using Clustal W, using BioEdit software package (Hall, 1999). The sequence was uploaded to GenBank (https://www.ncbi.nlm.nih.gov/genbank/). The Basic Local Alignment Search Tool (BLAST) was employed to find similarities in sequences in GenBank. The result is obtained in the form of a ranked list based on a normalized percent identity score, followed by individual sequence alignments (Madden, 2013)

\subsection{Climate matching}

In line with previous studies focused on environmental suitability of Indonesian territory for certain invasive species (Yonvitner et al., 2020), climate matching based on temperature characteristics was modelled from a dataset of environmental layers and the native range of Arapaima gigas using MaxEnt program (v.3.4.1; https://biodiversityinformatics. amnh.org/open source/maxent) in order to test its environmental suitability. MaxEnt is a maximum entropy model wellsuited for species distribution mapping (Phillips et al., 2006; Phillips and Dudík, 2008) and is widely used for predicting of spreading non-native species (Ward, 2007; Wang et al., 2010; Yonvitner et al., 2020). Available GPS coordinates of the native range were obtained from published records of studied species (Hrbek et al., 2007; Torati et al., 2019) and native occurrence records from the international biodiversity database GBIF (https://www.gbif.org). Environmental layers of historical climate data were obtained from the WorldClim database in the spatial resolution of $2.5 \operatorname{arcmin}\left(\sim 1 \mathrm{~km}^{2}\right)$ and environmental layers of future climate data (CSIRO A1B) were obtained from the CliMond database (v.1.2, https://www. climond.org/, (Kriticos et al., 2012) at a spatial resolution of 10 $\operatorname{arcmin}\left(\sim 1 \mathrm{~km}^{2}\right)$. Both datasets were assembled in QGIS 3.8.2 Zanzibar (https://qgis.org/en/site/) to ASCII format for use with the MaxEnt algorithm (Phillips, 2005). The final set of bioclimatic predictors comprised $\left({ }^{\circ} \mathrm{C}\right)$ : Annual Mean Temperature (BIO1), Mean Diurnal Range (BIO2), Isothermality (BIO3), Temperature Seasonality (BIO4), Max Temperature of Warmest Month (BIO5), Min Temperature of Coldest Month (BIO6), Temperature Annual Range (BIO7), Mean Temperature of Warmest Quarter (BIO10), Mean Temperature of Coldest Quarter (BIO11). The model described a continuous probability surface of habitat suitability in the target area. As the cumulative output, a continuous map was generated and visualised in QGIS 3.8.2 Zanzibar (https://qgis.org/en/site/). If the value of the climate match reached or exceeded the specific threshold value, this was interpreted as no evidence for climatic constraints to the survival of the species and it is shown in the red coloured area on the map.

\section{Results}

Based on personal investigation in the field, there are some local giant arapaima keepers who intentionally release the fishes into the wild in Indonesia (e.g., see the following link in Indonesian language: https://news.detik.com/video/180626091/ video-pelepasan-ikan-arapaima-di-sungai-brantas). In total, 27 individuals of giant arapaima were recorded in Indonesian freshwaters. Two of them were found in Sumatra and the others in Java (Fig. 1b). Recorded fish inhabited rivers, dams, natural pools beside rivers and dams, and artificial waterways recorded as canals (Tab. 1). All recorded individuals were adults with body length typically $>100 \mathrm{~cm}$. Some individuals of $A$. gigas were found dead in shallow waters, some were captured with use of spearfishing, angling or electrofishing. The captured fish were mostly consumed by local fishermen and their families or cut up and sold for human consumption (Fig. 2c and 2d).

The voucher specimen was a female with a total body length of $179 \mathrm{~cm}$ (Fig. 3) and mature eggs (i.e., vitellogenic oocytes) were found inside in its body cavity (Fig. 2a). Remains of unidentified Clarias catfish were found in its digestive tract (Fig. 2b). Based on both morphological and genetic analyses, the fish was identified as Arapaima gigas. The sequence of the voucher specimen is available in GenBank under Accession Number MT542128. The result obtained from BLAST showed $99.69 \%$ identity (100\% Query Cover) with the reference sequence GenBank Accession number EF523611 (Hrbek and Farias, 2008). The voucher specimen is deposited in the Bogor Zoology Museum, Indonesia.

MaxEnt calculated the threshold value of 11.25 and the model had an average training AUC value (area under the receiver-operator curve) of 0.99 suggesting a high predictability of the model (Ward, 2007; Elith et al., 2011). Based on climate matching, the probability of $A$. gigas to survive in vast areas of Indonesian territory is relatively high even if certain regions seem to be not so suitable and are shown as green areas on the map (Fig. 1a).

\section{Discussion}

Arapaima gigas is one of many species of ornamental fish pet-traded in Indonesia and we found adult individuals being released or escaping to freshwaters in Java and Sumatra. The species was first imported in 2005 (Sinovas et al., 2017) and more introduction events have been carried out in following years. Whether or not established, such a large and long-lived predator, as $A$. gigas, can be a serious threat to the rich native and partly endemic Indonesian fauna (Hutomo and Moosa, 2005). Endemic fish such as species from the genus Clarias can be at risk as suggested by food remains found in the digestive tract of the voucher specimen.

The growth rate of young $A$. gigas is rapid, up to a body length of $80 \mathrm{~cm}$ and weight of 4-5 kg in its first year of life (Val and Almeida-Val, 2012). The generation period is relatively slow, because $A$. gigas reaches sexual maturity in 4-5 years with a body length of $150-170 \mathrm{~cm}$ and weight of 40 $45 \mathrm{~kg}$ (Arantes et al., 2010). It is obvious that all the recorded individuals presented in this study were adults. In some cases, A. gigas was recorded as a single or two individuals in localities in Sumatra and western part of Java, but in the vicinity of Surabaya, the capital city of the Indonesian province of East Java and the second-largest city in the country, in total 22 individuals were recorded.

Arapaima gigas is socially monogamous, forming pairs, providing partitioned parental care including building a nest as a hole in the substrate which the fish digs with its mouth; it has been speculated that the nests are built in shallow waters 

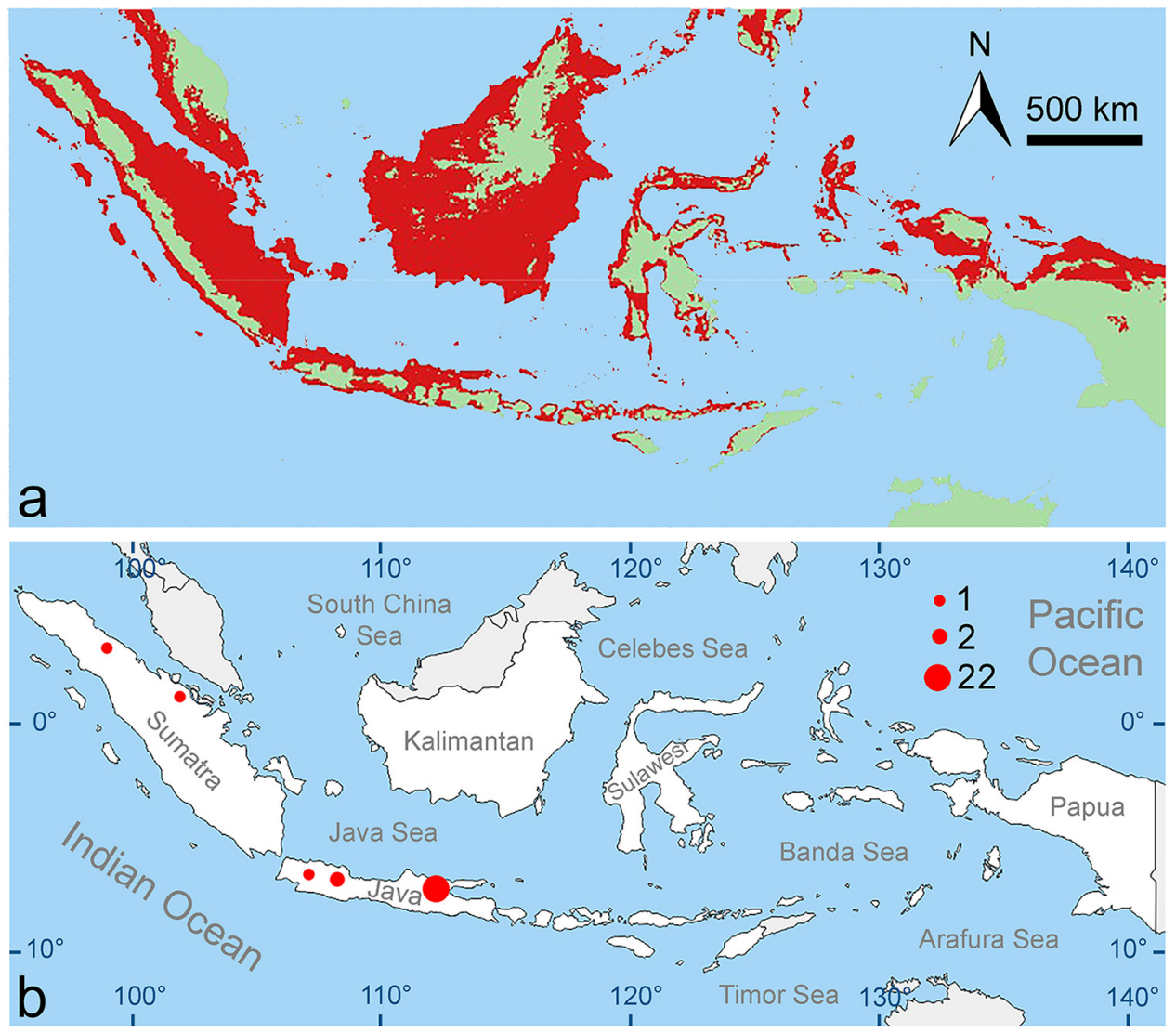

Fig. 1. Map of Indonesia: (a) showing environmental suitability for Arapaima gigas by the MaxEnt model whereas red colour represents a high probability of establishment; (b) records of A. gigas in Indonesia given by red dots (size corresponds to the number of individuals recorded).

(depth ca. $1 \mathrm{~m}$ ) in slower flowing streams and preferably in lentic lake water (Queiroz, 2000). Males stay with the brood and guard offspring while females leave and can even mate again in the same season (Castello, 2008). Both males and females have a secretory gland-like organ on the surface of their heads. This is mostly used for communication with offspring (Lüling, 1964) and it is more active in males who provides the greater part of parental care. The secretion from the glands also partially serves as a source of nutrition for fry (Du et al., 2019). Some authors suggested that at a certain stage in the development of fry, the males become mouthbrooders (Mendoza et al., 2015). No nesting activity or fry and juveniles were found in Indonesian wild but, since eggs were found in the adult female, successful reproduction and subsequent establishment cannot be excluded. The records of A. gigas from the wild fit with the output from climate matching.

Not only the biodiversity is at risk. Also, direct socioeconomic losses would be related with potential invasions of A. gigas because there are plenty of local fishermen in the regions where most specimens were found (the Mojokerto, Surabaya and Sidoarjo Districts in Java). Similarly as in Bolivia and Brazil, these people would be negatively affected by a potential decline of abundance and diversity of the native ichthyofauna caused by big predatory non-native fish such as A. gigas (Hadiaty, 2017). Moreover, many local Indonesian fishermen are afraid to go fishing in waters where arapaima occurs and say that their gill nets were damaged by this huge predatory fish (Jerikho, personal observation). On the other hand, one can speculate that some fishermen and local communities will adopt $A$. gigas for fishing and exploitation and hence, after some time this fish will be under heavy anthropogenic pressure, as it is in some places in Brazil.

On the other hand, abundance of native populations of A. gigas in Amazonia is declining rapidly and despite some conservation activities in Brazil, its future is at least uncertain (Parker, 2002). Thus, it is possible that this species could be eradicated out of its native range and should be very carefully considered because this fulfils the definition of the conservation paradox. In general, with regards to the conservation of endangered species, non-native populations can provide possibilities of how to help to save the species from extinction and bring some new insights into its biology and ecology (Marchetti and Engstrom, 2016). On the other hand, it is not acceptable to prefer saving of one species ex-situ and protect it at the expense of many others (in the case of the present study, the native/endemic ichthyofauna and other biota) which could become extinct due to this approach.

Using the Fish Invasiveness Screening Test (FIST), Magalhães et al. (2017a) indicated that A. gigas is a highrisk species in terms of biological invasions via aquarium dumping in Brazil. A possible solution could be a modification of legislative regulations focused on the pet trade. Caution is recommended in this regard (Patoka et al., 2018a) because new regulations can be easily misunderstood by fish keepers and traders who could consequently release them to the wild (i.e., aquarium dumping) to protect themselves from potential 
J. Marková et al.: Knowl. Manag. Aquat. Ecosyst. 2020, 421, 47

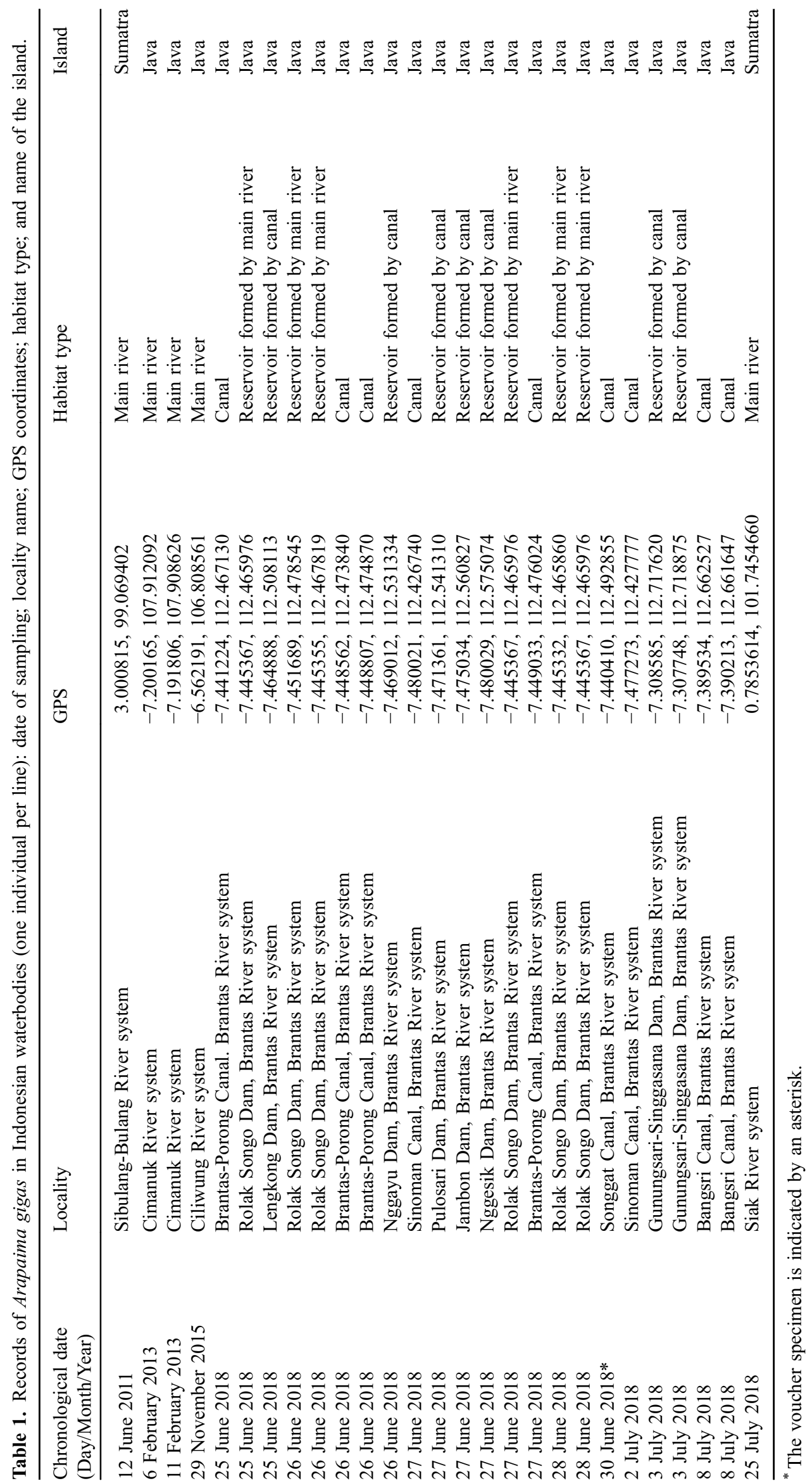



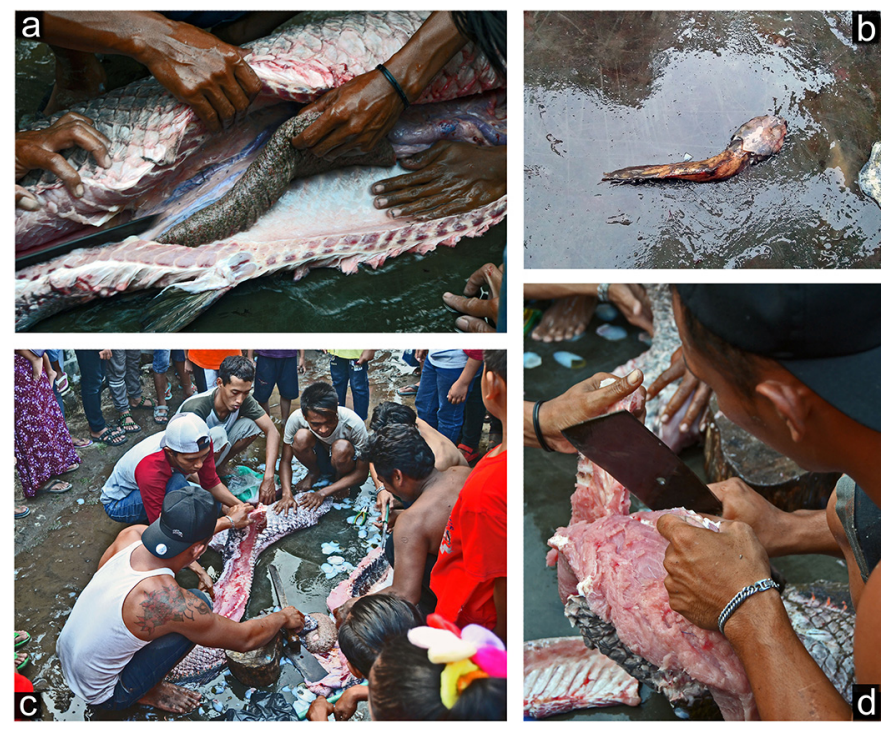

Fig. 2. Details about voucher Arapaima gigas: (a) ovary full of mature eggs (i.e., vitellogenic oocytes); (b) remain of unidentified Clarias catfish found inside in the digestive tract of the voucher specimen; (c, d) the meat cut up and subsequently consumed by local fishermen and their families.
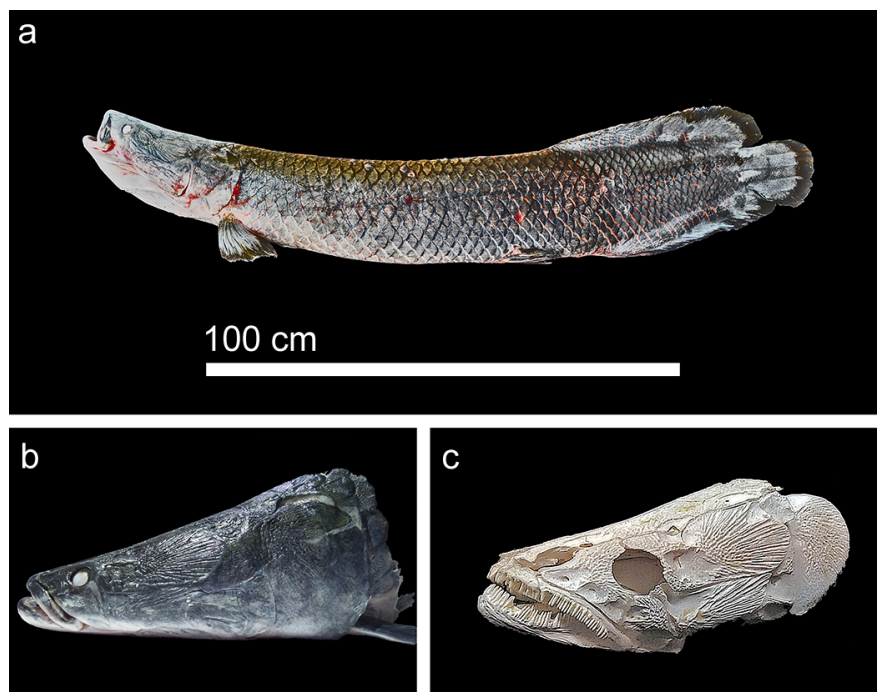

Fig. 3. Voucher specimen of Arapaima gigas captured in Indonesia: (a) adult female; (b) head in detail; (c) dissected skull.

sanctions. Simply, poorly prepared regulations would worsen the situation dramatically. Therefore, an intensive educational campaign is crucial before any further steps. The key is understanding the full impact of the introduced species on the ecosystem it is invading. Therefore, detailed monitoring focused especially on the feeding and reproductive ecology of A. gigas introduced in Indonesia is strongly recommended to understand its real impact on native biota and local fisheries.

Acknowledgements. Rikho Jerikho acknowledges the project "Ichthys-Alien Indonesia". This study was supported by the institutional support RVO: 60460709 (Czech University of
Life Sciences Prague). English was proofread by Julian D. Reynolds.

\section{References}

Arantes CC, Castello L, Stewart DJ, Cetra M, Queiroz HL. 2010. Population density, growth and reproduction of arapaima in an Amazonian river-floodplain. Ecol Freshw Fish 19: 455-465.

Araripe J, do Rêgo PS, Queiroz H, Sampaio I, Schneider H. 2013. Dispersal capacity and genetic structure of Arapaima gigas on different geographic scales using microsatellite markers. PLoS One 8: e54470.

Azevedo-Santos VM, Fearnside PM, Oliveira CS, Padial AA, Pelicice FM, Lima DP, Simberloff D, Lovejoy TE, Magalhães AL, Orsi ML. 2017. Removing the abyss between conservation science and policy decisions in Brazil. Biodivers Conserv 26: 1745-1752.

Baillie J, Groombridge B. 1996. IUCN red list of threatened animals. The IUCN Species Survival Commission.

Bellard C, Cassey P, Blackburn TM. 2016. Alien species as a driver of recent extinctions. Biol Lett 12: 20150623.

Bolotov IN, Bespalaya YV, Gofarov MY, Kondakov AV, Konopleva ES, Vikhrev IV. 2016. Spreading of the Chinese pond mussel, Sinanodonta woodiana, across Wallacea: one or more lineages invade tropical islands and Europe. Biochem Syst Ecol 67: 58-64.

Bradshaw CJ, Isagi Y, Kaneko S, Bowman DM, Brook BW. 2006. Conservation value of non-native banteng in northern Australia. Conserv Biol 20: 1306-1311.

Casazza ML, Overton CT, Bui T-VD, Hull JM, Albertson JD, Bloom VK, Bobzien S, McBroom J, Latta M, Olofson P. 2016. Endangered species management and ecosystem restoration: finding the common ground. Ecol Soc 21: 19.

Casimiro ACR, Garcia DAZ, Vidotto-Magnoni AP, Britton JR, Agostinho ÂA, Almeida FSd, Orsi ML. 2018. Escapes of nonnative fish from flooded aquaculture facilities: the case of Paranapanema River, southern Brazil. Zoologia 35: e14638.

Castello L. 2004. A method to count pirarucu Arapaima gigas: fishers, assessment, and management. N Am J Fish Manage 24: 379-389.

Castello L, Stewart DJ. 2010. Assessing CITES non-detriment findings procedures for Arapaima in Brazil. J Appl Ichthyol 26: 49-56.

Ceballos G, Ehrlich PR, Barnosky AD, García A, Pringle RM, Palmer TM. 2015. Accelerated modern human-induced species losses: Entering the sixth mass extinction. Sci Adv 1: e1400253.

Cristescu B, Boyce MS. 2013. Focusing ecological research for conservation. Ambio 42: 805-815.

da Costa Doria CR, dos Santos Catâneo DTB, Torrente-Vilara G, Vitule JRS. 2020. Is there a future for artisanal fishing in the Amazon? The case of Arapaima gigas. Manag Biol Invasions 11: $1-8$.

de Oliveira EG, Pinheiro AB, de Oliveira VQ, da Silva Júnior ARM, de Moraes MG, Rocha ÍRCB, de Sousa RR, Costa FHF. 2012. Effects of stocking density on the performance of juvenile pirarucu (Arapaima gigas) in cages. Aquaculture 370: 96-101.

Du K, Wuertz S, Adolfi M, Kneitz S, Stöck M, Oliveira M, Nóbrega R, Ormanns J, Kloas W, Feron R. 2019. The genome of the arapaima (Arapaima gigas) provides insights into gigantism, fast growth and chromosomal sex determination system. Sci Rep 9: 5293.

Duggan IC, Rixon CA, MacIsaac HJ. 2006. Popularity and propagule pressure: determinants of introduction and establishment of aquarium fish. Biol Invasions 8: 377-382.

Early R, Bradley BA, Dukes JS, Lawler JJ, Olden JD, Blumenthal DM, Gonzalez P, Grosholz ED, Ibañez I, Miller LP. 2016. Global 
threats from invasive alien species in the twenty-first century and national response capacities. Nat Commun 7: 12485.

Elith J, Phillips SJ, Hastie T, Dudík M, Chee YE, Yates CJ. 2011. A statistical explanation of MaxEnt for ecologists. Divers Distrib 17:43-57.

Ernst CH, Lovich J. 2009. Turtles of the United States and Canada, 2nd ed. Baltimore: Johns Hopkins University Press, 840 p.

Fadjar M, Islamy RA, Herawati EY. 2019. First record of Arapaima gigas (Schinz, 1822) (Teleostei: Osteoglossomorpha), in the Brantas River, Sidoarjo, East Java, Indonesia. Biodivers J Biol Divers 20: 3527-3531.

Ferreira E. 2013. Arapaimatidae. In Queiroz L, Torrente-Vilara G, Ohara W, Pires T, Zuanon J, Doria C, eds. Peixes do rio Madeira. Porto Velho: Dialeto Latin American Documentary, pp. 85-87.

Fontenele O. 1955. Contribuicao para o conhecimento da biologia do pirarucu Arapaima gigas (Cuvier), em cativeiro (Actinopterygii, Osteoglossidae) [Ceara, Brasil]. Rev Bras Biol 8: 445-459.

Forneck SC, Dutra FM, Zacarkim CE, Cunico AM. 2016. Invasion risks by non-native freshwater fishes due to aquaculture activity in a Neotropical stream. Hydrobiologia 773: 193-205.

Garzón-Machado V, del-Arco-Aguilar MJ, Pérez-de-Paz PL. 2012. Threat or threatened species? A paradox in conservation biology. $J$ Nat Conserv 20: 228-230.

Goulding M. 1980. The fishes and the forest: explorations in Amazonian natural history. Berkeley and Los Angeles: University of California Press, 280 p.

Gozlan RE, Whipps CM, Andreou D, Arkush KD. 2009. Identification of a rosette-like agent as Sphaerothecum destruens, a multihost fish pathogen. Int J Parasitol 39: 1055-1058.

Green SJ, Akins JL, Maljković A, Côté IM. 2012. Invasive lionfish drive Atlantic coral reef fish declines. PLoS One 7: e3259.

Hadiaty R. 2017. Arapaima gigas (Schinz, 1822), Ikan air tawar terbesar di dunia, exotis namun sangat berbahaya bagi ikan asli Indonesia. Warta Iktiologi 1: 20-26.

Hall TA. 1999. BioEdit: a user-friendly biological sequence alignment editor and analysis program for Windows 95/98/NT. Nucl Acid S 41: 95-98.

Héritier L, Valdeón A, Sadaoui A, Gendre T, Ficheux S, Bouamer S, Kechemir-Issad N, Du Preez L, Palacios C, Verneau O. 2017. Introduction and invasion of the red-eared slider and its parasites in freshwater ecosystems of southern Europe: risk assessment for the European pond turtle in wild environments. Biodivers Conserv 26: 1817-1843.

Hossain MS, Patoka J, Kouba A, Buřič M. 2018. Clonal crayfish as biological model: a review on marbled crayfish. Biologia 73: 841-855.

Hrbek T, Crossa M, Farias I. 2007. Conservation strategies for Arapaima gigas (Schinz, 1822) and the Amazonian várzea ecosystem. Braz J Biol 67: 909-917.

Hrbek T, Farias IP. 2008. The complete mitochondrial genome of the pirarucu (Arapaima gigas, Arapaimidae, Osteoglossiformes). Genet Mol Biol 31: 293-302.

Hrbek T, Farias IP, Crossa M, Sampaio I, Porto JI, Meyer A. 2005. Population genetic analysis of Arapaima gigas, one of the largest freshwater fishes of the Amazon basin: implications for its conservation. Anim Conserv 8: 297-308.

Hutomo M, Moosa MK. 2005. Indonesian marine and coastal biodiversity: Present status. Indian J Mar Sci 34: 88-97.

Ilheu M, Matono P, Bernardo JM. 2014. Invasibility of Mediterranean-climate rivers by non-native fish: The importance of environmental drivers and human pressures. PLoS One 9: e109694.

Imbiriba EP. 2001. Potencial de criação de pirarucu, Arapaima gigas, em cativeiro. Acta Amazon 31: 299.
Kalous L, Patoka J, Kopecký O. 2015. European hub for invaders: risk assessment of freshwater aquarium fishes exported from the Czech Republic. Acta Ichthyol Piscat 45: 239-245.

Kletou D, Hall-Spencer JM, Kleitou P. 2016. A lionfish (Pterois miles) invasion has begun in the Mediterranean Sea. Mar Biodivers Rec 9: 46.

Knight J. 2010. Invasive ornamental fish: a potential threat to aquatic biodiversity in peninsular India. $J$ Threat Taxa 2: 700-704.

Kouba A, Petrusek A, Kozák P. 2014. Continental-wide distribution of crayfish species in Europe: update and maps. Knowl Manag Aquat Ec 413: 31.

Kriticos DJ, Webber BL, Leriche A, Ota N, Macadam I, Bathols J, Scott JK. 2012. CliMond: global high-resolution historical and future scenario climate surfaces for bioclimatic modelling. Methods Ecol Evol 3: 53-64.

Kumar AB, Raj S, Arjun C, Katwate U, Raghavan R. 2019. Jurassic invaders: flood-associated occurrence of arapaima and alligator gar in the rivers of Kerala. Curr Sci 116: 1628-1630.

Lampert A, Hastings A, Grosholz ED, Jardine SL, Sanchirico JN. 2014. Optimal approaches for balancing invasive species eradication and endangered species management. Science 344: 1028-1031.

Lees AC, Bell DJ. 2008. A conservation paradox for the 21 st century: the European wild rabbit Oryctolagus cuniculus, an invasive alien and an endangered native species. Mammal Rev 38: 304-320.

Lever C. 2003. Naturalized reptiles and amphibians of the world. Oxford, New York: Oxford University Press, 344 p.

Liang S-H, Chuang L-C, Chang M-H. 2006. The pet trade as a source of invasive fish in Taiwan. Taiwania 51: 93-98.

Lima Junior DP, Magalhães ALB, Pelicice FM, Vitule JRS, AzevedoSantos VM, Orsi ML, Simberloff D, Agostinho AA. 2018. Aquaculture expansion in Brazilian freshwaters against the Aichi Biodiversity Targets. Ambio 47: 427-440.

Lockwood JL, Hoopes MF, Marchetti MP. 2013. Invasion Ecology. Chichester: Wiley-Blackwell, 312 p.

Lőkkös A, Müller T, Kovács K, Várkonyi L, Specziár A, Martin P. 2016. The alien, parthenogenetic marbled crayfish (Decapoda: Cambaridae) is entering Kis-Balaton (Hungary), one of Europe's most important wetland biotopes. Knowl Manag Aquat Ec 417: 16.

Lüling K. 1964. Zur biologie und ökologie von Arapaima gigas (Pisces, Osteoglossidae). Zeitschrift für Morphologie und Ökologie der Tiere 54: 436-530.

Madden T. 2013. The BLAST sequence analysis tool. In: The NCBI Handbook [Internet]. 2nd edition. National Center for Biotechnology Information (US), Available from: https://www.ncbi.nlm.nih. gov/books/NBK153387/

Maddern M, Gill H, Morgan D. 2011. Biology and invasive potential of the introduced swordtail Xiphophorus hellerii Heckel (Poeciliidae) in Western Australia. Aquat Conserv 21: 282-291.

Magalhães ALB. 2015. Presence of prohibited fishes in the Brazilian aquarium trade: effectiveness of laws, management options and future prospects. J Appl Ichthyol 31: 170-172.

Magalhães ALB, Jacobi CM. 2017. Colorful invasion in permissive Neotropical ecosystems: establishment of ornamental non-native poeciliids of the genera Poecilia/Xiphophorus (Cyprinodontiformes: Poeciliidae) and management alternatives. Neotrop Ichthyol 15: e160094.

Magalhães AL, Orsi ML, Pelicice FM, Azevedo-Santos VM, Vitule JR, Lima-Junior D, Brito MF. 2017a. Small size today, aquarium dumping tomorrow: sales of juvenile non-native large fish as an important threat in Brazil. Neotrop Ichthyol 15: e170033.

Magalhães ALB, Orsi ML, Pelicice FM, Azevedo-Santos VM, Vitule JR, Lima-Junior D, Brito MF. 2017b. Small size today, aquarium 
dumping tomorrow: sales of juvenile non-native large fish as an important threat in Brazil. Neotrop Ichthyol 15: e170033.

Marchetti MP, Engstrom T. 2016. The conservation paradox of endangered and invasive species. Conserv Biol 30: 434-437.

Marwoto RM, Nur NRI. 2011. Notes on the distribution of invasive freshwater snail Pomacea canaliculata (Lamarck, 1822) and P. insularum (d'Orbigny, 1835) in Indonesia. Biotropia 18:123-128.

Mendoza R, Luna S, Aguilera C. 2015. Risk assessment of the ornamental fish trade in Mexico: analysis of freshwater species and effectiveness of the FISK (Fish Invasiveness Screening Kit). Biol Invasions 17: 3491-3502.

Miranda-Chumacero G, Wallace R, Calderón H, Calderón G, Willink P, Guerrero M, Siles TM, Lara K, Chuqui D. 2012. Distribution of arapaima (Arapaima gigas) (Pisces: Arapaimatidae) in Bolivia: implications in the control and management of a non-native population. BioInvasions Rec 1: 129-138.

Muchlisin Z. 2012. First report on introduced freshwater fishes in the waters of Aceh, Indonesia. Arch Polish Fish 20: 129-135.

Muchlisin Z, Akyun Q, Halim A, Rizka S, Sugianto S, Fadli N, SitiAzizah M. 2015. Ichthyofauna of Tripa peat swamp forest, Aceh province, Indonesia. Check List 11: 1560.

Mueller O, Green A. 2005. Arapaima gigas - market study: current status of arapaima global trade and perspectives on the Swiss, French and UK markets. Cocha El Dorado: UNCTAD, 51 p.

Nijman V. 2010. An overview of international wildlife trade from Southeast Asia. Biodivers Conserv 19: 1101-1114.

Nobile AB, Cunico AM, Vitule JR, Queiroz J, Vidotto-Magnoni AP, Garcia DA, Orsi ML, Lima FP, Acosta AA, Silva RJ. 2019. Status and recommendations for sustainable freshwater aquaculture in Brazil. Rev Aquacult. https://doi.org/10.1111/raq.12393

Novák J, Kalous L, Patoka J. 2020. Modern ornamental aquaculture in Europe: early history of freshwater fish imports. Rev Aquacult. https://doi.org/10.1111/raq.12421

Padilla DK, Williams SL. 2004. Beyond ballast water: aquarium and ornamental trades as sources of invasive species in aquatic ecosystems. Front Ecol Environ 2: 131-138.

Parker BH. 2002. Arapaima: An Amazonian fish species of immense proportions. Biodiversity 3: 21-24.

Pârvulescu L, Togor A, Lele S-F, Scheu S, Șinca D, Panteleit J. 2017. First established population of marbled crayfish Procambarus fallax (Hagen, 1870) f. virginalis (Decapoda, Cambaridae) in Romania. BioInvasions Rec 6: 357-362.

Patoka J. 2018. Akvaristika v Indonésii: je libo arapaimu, kostlína či geneticky modifikovaná dánia? Akvárium 40: 52-65.

Patoka J, Kalous L, Kopecký O. 2015. Imports of ornamental crayfish: the first decade from the Czech Republic's perspective. Knowl Manag Aquat Ec 416: 9.

Patoka J, Kopecký O, Vrabec V, Kalous L. 2017. Aquarium molluscs as a case study in risk assessment of incidental freshwater fauna. Biol Invasions 19: 2039-2046.

Patoka J, Magalhães ALB, Kouba A, Faulkes Z, Jerikho R, Vitule JRS. 2018a. Invasive aquatic pets: failed policies increase risks of harmful invasions. Biodivers Conserv 27: 3037-3046.

Patoka J, Wardiatno Y, Mashar A, Wowor D, Jerikho R, Takdir M, Purnamasari L, Petrtýl M, Kalous L, Kouba A. 2018b. Redclaw crayfish, Cherax quadricarinatus (von Martens, 1868), widespread throughout Indonesia. BioInvasions Rec 7: 185-189.

Patoka J, Prabowo RE, Petrtýl M, Reynolds J, Kuř́ková P, Zámečníková-Wanma B, Kalous L. 2020a. Marine hitchhikers: a preliminary study on invertebrates unintentionally transported via the international pet trade. NeoBiota 61: 33-36.

Patoka J, Takdir M, Yonvitner AH, Jerikho R, Nilawati J, Tantu FY, Bohatá L, Aulia A, Kamal MM, Wardiatno Y, Petrtýl M. 2020b.
Two species of illegal South American sailfin catfish of the genus Pterygoplichthys well-established in Indonesia. Knowl Manag Aquat Ec 421: 28.

Phillips SJ. 2005. A brief tutorial on Maxent. AT\&T Research. ncep. amnh.org/linc/ ( accessed June 16, 2020)

Phillips SJ, Dudík M. 2008. Modeling of species distributions with Maxent: new extensions and a comprehensive evaluation. Ecography 31: 161-175.

Phillips SJ, Anderson RP, Schapire RE. 2006. Maximum entropy modeling of species geographic distributions. Ecol Model 190: 231-259.

Pimentel D. 2014. Biological invasions: economic and environmental costs of alien plant, animal, and microbe species. Boca Raton: CRC Press, $463 \mathrm{p}$.

Priono B, Satyani D. 2010. Sekilas Tentang Beberapa Jenis Ikan Hias Air Tawar Yang Dilarang Masuk ke Indonesia. Media Akuakultur 5: $102-108$

Putra MD, Bláha M, Wardiatno Y, Krisanti M, Jerikho R, Kamal MM, Mojžišová M, Bystřický PK, Kouba A, Kalous L, Petrusek A, Patoka J. 2018. Procambarus clarkii (Girard, 1852) and crayfish plague as new threats for biodiversity in Indonesia. Aquat Conserv 28: $1434-1440$.

Queiroz HL. 2000. Natural history and conservation of pirarucu, Arapaima gigas, at the Amazonian Várzea: red giants in muddy waters. Dissertation, University of St. Andrews.

Radford CC. 2011. The endangered wattle-necked softshell turtle (Palea steindachneri) throughout the Hawaiian Islands. Dissertation, California State University.

Ramos TPA, Ramos RTdC, Ramos SAQ. 2014. Ichthyofauna of the Parnaíba river basin, northeastern Brazil. Biota Neotrop 14: $1-8$.

Ramsay NF, Ng PKA, O'Riordan RM, Chou LM. 2007. The red-eared slider (Trachemys scripta elegans) in Asia: a review. In: Gherardi F, ed. Biological invaders in inland waters: profiles, distribution, and threats. Dordrecht: Springer, pp. 161-174.

Schofield PJ, Jelks H, Gestring KB. 2019. Eradication of two nonnative cichlid fishes in Miami, Florida (USA). Manag Biol Invasion 10: $296-310$.

Shiu H, Stokes L. 2008. Buddhist animal release practices: historic, environmental, public health and economic concerns. Contemp Buddhism 9: 181-196.

Sinovas P, Price B, King E, Hinsley A, Pavitt A. 2017. Wildlife trade in the Amazon countries: an analysis of trade in CITES listed species. Technical Report Prepared for the Amazon Regional Program. UN Environment World Conservation Monitoring Centre. https://doi.org/10.13140/RG.2.2.33501.00482

Stewart DJ. 2013. A new species of Arapaima (Osteoglossomorpha: Osteoglossidae) from the Solimões River, Amazonas State, Brazil. Copeia 2013: 470-476.

Torati LS, Taggart JB, Varela ES, Araripe J, Wehner S, Migaud H. 2019. Genetic diversity and structure in Arapaima gigas populations from Amazon and Araguaia-Tocantins river basins. BMC Genet 20: 13.

Val AL, Almeida-Val VMF. 2012. Fishes of the Amazon and their environment: physiological and biochemical aspects. Berlin Heidelberg: Springer, $235 \mathrm{p}$.

Van Damme PA, Méndez CC, Zapata M, Carvajal-Vallejos FM, Carolsfeld J, Olden JD. 2015. The expansion of Arapaima cf. gigas (Osteoglossiformes: Arapaimidae) in the Bolivian Amazon as informed by citizen and formal science. Manag Biol Invasion 6: 375-383.

Vellend M. 2017. The biodiversity conservation paradox. Am Sci 105: 94-101. 
Vidthayanon C. 2005. Aquatic alien species in Thailand (Part1): Biodiversity. In: International mechanisms for the control and responsible use of alien species in aquatic ecosystems. Report of an ad hoc expert Consultation. People's Republic of China, Xishuangbanna, pp. 113-118.

Wang X, Huang X, Jiang L, Qiao G. 2010. Predicting potential distribution of chestnut phylloxerid (Hemiptera: Phylloxeridae) based on GARP and Maxent ecological niche models. J Appl Entomol 134: 45-54.

Ward DF. 2007. Modelling the potential geographic distribution of invasive ant species in New Zealand. Biol Invasions 9: 723-735.
Ward RD, Zemlak TS, Innes BH, Last PR., Hebert PD. 2005. DNA barcoding Australia's fish species. Philos $T$ Roy Soc B 360: $1847-1857$.

Wood E. 2001. Collection of coral reef fish for aquaria: global trade, conservation issues and management strategies. Aquar Sci Conserv 3: 65-77.

Yonvitner Y, Patoka J, Yuliana E, Bohatá L, Tricarico E, Karella T, Kouba A, Reynolds J. 2020. Enigmatic hotspot of crayfish diversity at risk: invasive potential of non-indigenous crayfish if introduced to New Guinea. Aquat Conserv 30: $219-224$.

Cite this article as: Marková J, Jerikho R, Wardiatno Y, Kamal MM, Magalhães ALB, Bohatá L, Kalous L, Patoka J. 2020. Conservation paradox of giant arapaima Arapaima gigas (Schinz, 1822) (Pisces: Arapaimidae): endangered in its native range in Brazil and invasive in Indonesia. Knowl. Manag. Aquat. Ecosyst., 421, 47. 